\title{
Bordering Shanghai: China's Hukou system and processes of urban bordering
}

\begin{abstract}
:
As members of history's largest rural-urban migration, the migrants who make up a great portion of urban China's low-wage labor force and burgeoning population face unique challenges. Although the trajectories of their movements do not cross international boundaries, most are legally prevented from ever gaining full legal status in their destinations, based on the status they hold within China's hukou system of household registration. This system parallels national citizenship policies in important ways, providing an alternative to standard understandings of how the legal boundaries around communities are drawn. However, empirical work bringing the hukou system into relation with theoretical developments in (international) migration studies is scarce. Based on a series of qualitative interviews conducted in Shanghai and rural Anhui province, this article argues that the structure and effects of the hukou system demonstrate clearly that the boundaries of national territory cannot be considered as the exclusive site from which bordering processes emanate. Bridging the gap between scholarship of Chinese migration and international boundary-making, I position this argument as an extension of the recent trend in border studies to understand bordering processes as taking place beyond the territorial boundaries of the nation state.
\end{abstract}

Key Words: Bordering; Internal Migration; China; Hukou; Shanghai; Urban Citizenship

Leif Johnson

University of Kentucky

817 Patterson Office Tower

Lexington, KY 40506-0027

a.leif.johnson@gmail.com

\section{Acknowledgments:}

This research would not have been possible without help from all corners. Thanks to Li Zhang and the School of Social Development and Public Policy at Fudan University for providing me with the research support that made this project possible in the first place, and to Yuan Jing and Miao Jiaju for unflagging support in research and their language proficiency. Thanks are also due to Emily Kaufman, Matthew Rosenblum, Mitch Snider, Sue Roberts, and Patricia Ehrkamp for patient readings, commentary, support in the writing process. Thanks are also due to the two anonymous reviewers whose commentary played an integral role in clarifying and strengthening my argument through the publication process. This project was supported by the National Science Foundation, Ministry of Science and Technology of the People's Republic of China, and the Chinese Academy of Sciences through the joint East Asia and Pacific Summer Institute program, NSF award number 1414810. 


\section{Introduction}

The scale of migrant workers' contributions to China's rise as an economic superpower is impossible to overstate. Looking out the window of the conference room where we had met for an interview, one of my research participants said it best as he gestured to the glittering skyline of central Shanghai: "Without them, buildings like this could not be built." The more than 200 million members of China's so-called "floating population" (liudong renkou) - at least 166 million of whom are classified as low-wage "peasant migrants" (waichu nongmingong) - have played a profound role in reshaping China's urban and cultural landscape (Fan 2008; China Statistical Bureau 2014; Sun 2014). Rural-urban migrations taking place worldwide often coincide with striking inequalities and patterns of social exclusion (e.g. Davis 2006). What sets China's internal migrants apart are the additional legal barriers they face: Through the hukou system of household registration, political membership in a given urban or rural community has a significant influence on individuals' life chances, and most of this vast migrant population is excluded from legal membership in the urban areas where they reside.

Developing from a multifaceted historical role as a population registry and eventual integration into the state-planned economy in the years after 1949, the contemporary hukou system functions as a powerful tool for internal migration management, particularly in China's largest cities. Through an examination of the ways this system structures and manages migration, this article points to structural and functional overlaps between hukou policy in Shanghai and other Tier 1 Chinese cities, and the increasingly expansive bordering processes employed by many high-income migrant-receiving nation states. This recognition that bordering processes take place at sub-national scales opens myriad spaces for theoretical engagement between border scholarship and a variety of historical and contemporary border-making processes.

The article is structured as follows: After a brief discussion of the historical development 
of the hukou system (Section 1.1) and the critical border studies literature this article draws on to discuss the role of the hukou system as a bordering process (Section 1.2), I describe the study's methodology (Section 2) before returning to the theoretical implications of its argument. In Section 3, I explore similarities between the construction of bordering processes within China and in the international context, finding that despite differences in the means of implementation, there are conceptual kinships between the guiding principles that animate Shanghai's hukou system and international bordering (Section 3.1) and specific tools employed for the purpose of implementing these strategies (Section 3.2).

\subsection{Contextualizing the hukou system}

The contemporary hukou system is deeply influenced by the historical context in which it has operated, first as a central element of the Chinese planned economy and later as one of the principle systems managing labor migration in the reform era. While it is impossible to fully review here, I offer a brief overview of the system below.

While the system's conceptual underpinnings may be linked historically to the baojia system for registering households in premodern China, whose history stretches back as far back as 685 BC (Zhu 2003; Fan 2008). The hukou system as such was first and foremost developed as a central tool for social control in the early Communist period (Chan and Zhang [1] 1999) - a modern incarnation of the hukou that is also linked to the Soviet propiska system of "internal passports" which regulated internal mobility within the USSR through the 1980s (Pipko and Pucciarelli 1985; Buckley 1995). Initial constraints on migration through the hukou were first announced in 1958, and began to be strongly enforced in 1960. These restrictions were primarily intended to stem the so-called "blind flow" (mangliu) of peasants gravitating to coastal urban areas (Cheng and Selden 1994; Fan 2008). The system gained considerable power when, from 
the 1960s through 1980s, the distribution of food to urban residents was dependent on hukou status, making autonomous migration into urban areas very difficult, if not impossible (Cheng and Selden 1994, 645). During this period, most movement was possible only with the blessing of the state, granted only when state enterprises needed access to rural labor (Chan and Zhang [1] 1999). This represented a significant shift away from the Soviet system, and resulted in a much more effective control on population movements for over two decades (Buckley 1995).

Since its implementation, the hukou system has gone through significant structural changes. While the most significant of these took place during the period of economic restructuring beginning in 1979 , the past thirty years have seen a wide variety of additional reforms (Chan and Zhang [1] 1999; Fan 2008; Zhang [1] and Tao 2012). Movement to coastal urban areas became a possibility following the implementation of market reforms in the last years of the 1970s and early 1980s - a development that led to the sharp rise in rural-urban migration through the 1980s and 90s. This migration has been nominally formalized since 1985 , when destination cities began to require migrants to register for temporary residence permits (juzhu zheng or zanzhu zheng - hereafter referred to as TRP) which must be renewed after a defined period - from three months to two years depending on regulations in the issuing municipality (Chan and Zhang [1] 1999). The TRP does not offer its holder the same rights as a hukou transfer. For readers familiar with U.S. or European immigration policy, a close analogy is the difference between a guest worker program which legalizes long-term residence through intermittent renewal, but provides no path to citizenship that would formalize permanent membership in a nation-state (W. Li 2013; Surak 2013).

Most recently, the decentralization of hukou administration and injunctions to many smaller cities to issue hukou to their non-registered or TRP-holding populations have been heralded as a sign that China may be "abolishing" the system. However, this decentralization has 
in fact lead to higher barriers to entry in China's largest cities, and reforms aimed at increasing development in smaller cities through easy hukou transfer have been implemented alongside tightening restrictions in China's largest cities, with Shanghai taking the lead in developing new legal technologies to manage which migrants are granted full legal status (Chan and Buckingham 2008; Zhang [1] and Tao 2012; Goodburn 2014).

Myriad benefits and rights are contingent on hukou status, including access to most statefunded social programs, as well as those jointly funded through mandatory employer contributions and state funds: Public health insurance, state pensions, subsidized housing, and employment in state-owned firms ${ }^{1}$ (Fu et al. 2007; Zhang [1] and Li 2016). The non-portability of public health insurance is one important factor reinforcing spatial divides in healthcare outcomes (Y. Li et al. 2016). Until recently, children without local hukou status were also forbidden from attending public school in urban areas; although recent policy changes have attempted to provide increased access for migrant children, many remain excluded as a result of a variety of official and semi-official factors (Goodburn 2009; Lai et al. 2014). Research has also shown that in Shanghai, Shenzhen and Beijing migrants are also significantly disadvantaged in terms of access to affordable housing when compared to local hukou holders, although in Shanghai this gap is somewhat less acute than in Beijing and Shenzhen, due to the relatively larger volume of private-sector housing (Hui, Yu, and Ye 2014, 1387).

Taken together, these legal exclusions represents a spatialized bifurcation of the urban population between migrants and locals that functions alongside but apart from other divides

1 The ability to be employed in state-owned enterprises is an important divide in contemporary China, as the provision of many kinds of state welfare has historically been administered through state-run work units (danwei). 
such as those that separate by class and income, party membership, and ethnic identity ${ }^{2}$. Unlike these other impediments to the construction of the harmonious society that has been promoted by the central government since the mid-2000s, the hukou system operates on a purely spatial level, dividing residents of China's largest cities according to their possession or lack of local hukou. Hukou administration is also spatially diverse in itself: Since the implementation of policies decentralizing hukou administration, the regulation of hukou transfers is implemented by local governments, rather than the central government. As a result, Shanghai - as a province-level municipality - has significant authority to regulate its own hukou policies, and has led the way for other Tier 1 cities in reformulating the rules that define eligibility for hukou transfers (Zhang [1] and Tao 2012; discussed further in section 3.2). In Shanghai and beyond, the rule generally holds that the larger the city, the higher the bar for obtaining local hukou (Zhang [1] and Tao 2012). Thus, the legal structure of the hukou system is closely linked to politics surrounding the gap between the fortunes of China's largest cities and the rest of the country: Access to class status and economic advancement - the question of who, in Deng Xiaoping's famous words, will "get rich first" - is upheld in part by the explicit legal categorization of who belongs where.

\subsection{Hukou and the urban border}

Unlike the national borders that dominate border studies discourse, spatial divisions created by the hukou system are not rooted at the territorial limits of a sovereign state. Accordingly, examinations of the hukou offers a compelling perspective on the conditions of border-making that take place apart from or alongside the bounding of national territory. In

2 While extra-legal exclusions are not the focus of this article, see excellent work by Pun Ngai, whose excellent Made in China (2005) provides an incisive characterization of the way that language and local identities are used to control labor and mobility in one Guangdong factory, and by Sun Wanning, whose Subaltern China (2014) examines the place of migrant workers in cultural production. 
examining the system along these lines, this paper has two theoretical goals: First, to provide deeper and more robust points of reference and comparison to support recent Western borderstudies scholarship that has already begun to recognize the relevance of Chinese case to broader theorizations of border-making (e.g. Bloemraad, Korteweg, and Yurdakul 2008; McNevin 2013; Mezzadra and Neilson 2013). Second, this article places the migration-management strategies that have been employed in Shanghai as a case study in literatures focusing on the shaping of migration management policies, bridging theoretical work done in the field of critical border studies and in literature that discusses migration control at the urban, rather than international, scale.

That national territories have been at the center of theories of migration and bordermaking is perhaps not surprising, and can be attributed in part to what Andreas Wimmer and Nina Glick-Schiller (2002a; 2002b) have called methodological nationalism - the "assumption that the nation/state/society is the natural social and political form of the modern world" (Wimmer and Glick Schiller 2002b, 301) that both effects and is reproduced by theorists' tendency to imagine "a social world divided into bounded, culturally specific units typical of nationalist thinking (ibid, 305)." Despite this theoretical blind spot however, there are numerous examples of internal (and, particularly, urban) border-making taking place worldwide, from Latin America (e.g. Freeman 2003; Jirón 2010; Bocarejo 2012) to Thailand (Gullette 2014). However, these empirical examples have not been taken up in internationally-focused border and migration theories, nor have they integrated many of the theoretical developments that have arisen from this body of literature. While the case of the hukou system and migration management in urban China is unique in its scope and explicit legality (see Chan and Zhang [1] $1999,830)$, my hope in this essay is that it can provide a case study for a greater integration of research on boundary making across scales. 
Such an integration is particularly timely in light of the conspicuous departures from classical imaginations of the border that have emerged under the broad banner of critical border studies, which has begun to consider the ways that borders are often omnipresent, contingent, or otherwise detached from hard territorial lines. Pushed by the emergence and subsequent disavowal of globalization-driven narratives of "disappearing borders" (Newman and Paasi 1998), theories of international bordering have had to think beyond the classical definition of borders as the static boundaries of state territory (e.g. Prescott 1987). On one hand, researchers have investigated the questions of how borderwork - that is, the work of "envisioning, constructing, and maintaining borders" (Rumford 2008) - plays out as an element of local or regional politics within national territories, at their boundaries and far beyond them (Gilbert 2009; Coleman and Kocher 2011; Walker and Leitner 2011). On the other hand, scholarship has focused on the implementation of borders and bordering at the supranational level, with a particular focus in Europe on the creation of the shared Schengen border system (VaughanWilliams 2008; Scott and van Houtum 2009; van Houtum 2010; Andrijasevic and Walters 2010). These theoretical developments have made it possible to imagine bordering as porous, mobile, omnipresent, managerial - and, most importantly, taking place beyond the boundaries of a given national territory.

In summarizing the outcome of a pair of workshops on non-territorial bordering, Noel Parker, Nick Vaughan-Williams, and other participants persuasively argue that the developments indicated above have fundamentally changed the landscape of how we understand the border itself. In response, they call for a new approach - one that might "extrapolate new border concepts, logics, and imaginaries that capture the changing perspective on what borders are supposed to be and where they may be supposed to lie $(2009,583)$ " Responding to this need for new conceptions of borders, this article demonstrates the value of work that tracks the cross- 
fertilization between international bordering and processes of boundary-making that lack roots in national territory. Following a brief discussion of methodology and site-selection, I move into an empirically-based discussion of the theoretical and practical place the hukou system might take in theories of legal boundary-making.

\section{Methods}

Through the following sections, I bring together narratives and testimony from my own research, literature on Chinese internal migration and the hukou system, and theoretical developments from border and citizenship studies. Empirical content presented here is based on interviews carried out during Summer and Fall of 2014. I conducted eight interviews and one focus group with migrants and local residents in Shanghai (15 total participants), as well as six interviews and one focus group (11 total participants) in a rural community near outlying Wuhu City, Anhui province, where outmigration to Shanghai is a common household strategy. All interviews were conducted with the assistance of one of two local graduate students (one originally from Anhui, another originally from Jiangsu) who acted as intermittent interpreters, assisting in particular with regional dialects that I am not familiar with. Sampling was eclectic and intended to draw out a wide range of ages, types of employment, and experiences with migration. This resulted in a shallow but relatively broad sample. Although snowball sampling led to an overrepresentation of Anhui-Shanghai migrants, the interview sample also includes migrants hailing from Shandong, Sichuan, and Jiangsu provinces. All in all, interviewees included retired Shanghai population-statistics department members, academics, young Shanghainese finance workers, shop owners in the formal and informal sectors, service workers, and family members of migrants working in a variety of other sectors. Despite the broad range of experiences related in interviews and their open-ended nature, interviews were brought together 
by a unifying focus on interviewees' perceptions of the hukou system itself, as well as experiences of migration (or lack thereof) and views on the phenomenon as a whole. All names included here are pseudonyms.

I chose Shanghai as a field site because of its long history as a magnet for migration and current role as a leader in hukou policy change. While much work on internal migration focuses on the Pearl River Delta cities that are the most prominent migrant destination, as well as the largest manufacturing center in China, most of China's large cities attract significant migrant populations. Shanghai has been an important migrant destination since its rise as a forciblyopened "treaty port" in 1842, and remains so. Data from the 2010 census indicates that $38 \%$ of the city's population - nearly nine million people - were counted as part of the "floating population," having stayed in the city for over six months without local hukou. An additional 2.24 million people were counted as "short-term" floaters who had stayed in the city for less than 6 months at the time of census recording - a statistic that undoubtedly includes a mix of tourists and newly-arrived migrants (Shanghai Statistical Bureau 2011). This large population holding temporary residence permits in Shanghai is subject to local hukou regulations that make official hukou transfer and permanent migration to the city more difficult than in any other urban area in China (Zhang [1] and Tao 2012, 2891).

Anhui province, where my rural interviews were carried out, is one of the largest sources of migrant labor for Shanghai (Fan 2008). This was evident in discussions with community members I talked to, most of whom had performed migrant labor themselves or had family members who were currently working in Shanghai or other cities. The village I worked in, identified here pseudonymously as Taoyangcun, lies a few kilometers outside of Wuhu city, a prefecture-level city in Anhui province with a population of over 1 million people. There are a variety of options for work outside of the village, including Wuhu City and Nanjing, which is 
only 90 kilometers away. Nevertheless, Shanghai - over 300 kilometers distant - was the preeminent migrant destination among villagers I spoke to.

\section{$3 \quad$ Bordering through the Hukou system}

The remainder of this article consists of two connected juxtapositions placing the hukou system alongside international border policies. In section 3.1, I address the guiding assumptions that shape the hukou into a citizenship structure that is deeply entangled with the construction of spatial boundaries. In section 3.2 I focus on specific examples of shared mechanisms for the management of these boundaries, centering my analysis on the construction of incentives to circular migration as part of the hukou system's management structure, as well as Shanghai's pioneering role in implementing points systems to determine eligibility for urban citizenship. By examining the functionality of the hukou system through the lens of these two juxtapositions, I move toward functional understandings of borders that ask what work they do.

\subsection{Constructing Urban Citizenship}

This section explores narratives that legitimate restrictive hukou policy by constructing migrants as outsiders in Shanghai and other migrant-receiving cities in China, using narratives of resource scarcity common to both international citizenship policies and hukou management in Shanghai as a key point for theoretical integration. In drawing these connections, I follow existing literature that suggests that China's hukou system parallels national citizenship policies. Although there have been some gestures in the broader citizenship literature toward the applicability of theories of citizenship to internal migration in China (e.g. Bloemraad, Korteweg, and Yurdakul 2008, 155; McNevin 2013, 54), most conceptualizations of citizenship remain tightly wedded to the nation-state. 
Scholars have drawn specific and important comparisons between the hukou system and classical conceptions of citizenship. In particular, Dorothy Solinger's 1999 book Contesting Citizenship in Urban China has provided the groundwork for scholarship that followed, arguing that the hukou system constitutes a de-facto urban citizenship policy (Solinger 1999b). In a separate article, Solinger makes the relevance of her case to the international context explicit through a comparison of China's hukou system and the strict citizenship and immigration policies at work in Germany and Japan, arguing that in all three cases, states found economic success through the recruitment of migrant laborers who by and large have been unable to obtain full membership in their adoptive communities (Solinger 1999a). More recently, researchers have largely accepted the concept of hukou as citizenship, whether in discussions of specific aspects of the hukou system (Zhang [1] 2002; Smart and Smart 2001; Zhang [1] 2011) or in broader discussions of the relationship between the hukou system and other registers of citizenship within China (Guo 2014).

Scholarship that examines the hukou system as a subnational citizenship policy has made vital contributions to understandings of how migrants are constructed as outsiders and how this policy affects their daily lives. Nevertheless, this scholarship has not deeply engaged with the spatial bordering functions of citizenship. Following Linda Bosniak's (2008) argument that citizenship must be seen as a boundary concept, I see the elaboration of citizenship norms at both national and subnational scales as inextricably linked with processes of spatial boundary-making. If the concept of the border marks spaces of contingent belonging, citizenship both demarcates who this belonging applies to and what it might mean to belong. However, the great majority of contemporary scholarship explores citizenship at the level of the nation-state. As Engin Isin notes, while historical narratives that place the concept's origin in the Greek city-states might tie it to urban, rather than national, communities $(2002,1-51)$, the genealogy of modern citizenship 
demonstrates a deep and abiding alignment to the nation-state (Isin 2004). Echoing Wimmer and Glick-Schiller's critique of methodological nationalism (Wimmer and Glick Schiller 2002a; Wimmer and Glick Schiller 2002b), Bosniak problematizes the "normative nationalism" present in both theoretical and popular imaginations of citizenship (Bosniak 2008, 134-35) - a set of largely unquestioned norms privileging co-nationality while downplaying other forms of attachment that nevertheless look much like national citizenship.

In the case of Shanghai's hukou system, understandings of limited territory, threats of destabilization through mass migration, and the need to safeguard limited resources for the benefit of the deserving that are prevalent in much of the discourse around national citizenship are replicated at the urban scale. In my interviews, Shanghai locals, officials, and migrants alike justified the hukou system by arguing that without tight restrictions on hukou conversion, migrants would flood into Shanghai, decreasing stability and overloading services. As one member of a group of young Shanghainese finance professionals I interviewed put it, the removal of the hukou system would result in "a flow [of migrants] to the big cities that would exceed the maximum of burden of that city." Guo Tai, a Shanghainese professor who works with the Shanghai government on social development policy, offers a similar point, arguing that while the hukou system must eventually be replaced, its current role in maintaining social stability is crucial: "You know in China now, if we were to just cancel the hukou system, people could flow everywhere, and it could be dangerous to the government, to the society. This is why the hukou system is still very strong and stabilizing factor many places." Zhu Baiyue, a retired civil servant with decades of experience in the Shanghai population-statistics department, corroborates and elaborates on this idea, and clarifies the ways that urban citizenship must serve as a management system that protects cities' ability to provide services to urban citizens:

If you ask me, I think the [hukou] system is still necessary. If it was no longer there. 
Shanghai... Shanghai doesn't have the resources of a whole province, it really is just a bit of land (yi kuai di fang). So there still needs to be some kind of a threshold. I think the [hukou] system is still necessary, because if it wasn't there, everyone would come and I think it would be really problematic. From management to resources, there could be problems across all sectors. [As a result,] I reckon the [hukou] system won't be opened up for a long time.

In this discourse of stability, Shanghai, as well as China's other largest cities, are in danger of becoming overwhelmed by a flow of migrants. While it is universally acknowledged that the city depends on migrants, it at the same time must avoid out-of-control population growth. In particular, granting migrants urban citizenship would result in a vast and unmanageable drain on public resources.

The results of this concern that migrants' access to services might function as a drain on local government services can be seen clearly in the case of healthcare. While this case focuses on medical care specifically, similar divides can be found in other areas, including the provision of public education, old-age insurance, and housing (Goodburn 2009; Lai et al. 2014; Z. Li and Wu 2008). One of the most important services currently reserved for local hukou holders in Shanghai and other super-large cities is a relatively robust state-mandated healthcare policy. While migrants do have access to basic outpatient care services in some cities, subsidized funding for specialized services and any inpatient care is restricted to holders of local hukou (Zhang [1] and Li 2016, 5). State-mandated basic insurance policies form a crucial part of the healthcare system across China, but these services are linked to the place of hukou registration and as a result are not portable (Y. Li et al. 2016). This system is predicated on the assumption that migrants, as non-local, temporary residents, have access to medical care in their places of origin. Of course, these services are often far away, difficult to access, and in most cases function at lower standards of care than those that can be found in urban areas. Shanghai, however, offers what is likely the best medical system in China (Zhang and Kanbur 2005, 194), although this 
level of quality is most often not open to migrants.

The physical effects of the spatial and legal divide between migrant "temporary residents" and urban citizens are visible in an interview I carried out with Xiaohua, a middleaged migrant woman from Jiangsu province, who became deeply emotional as we discussed the difficulties she found in accessing medical care. Her daughter had been diagnosed with leukemia at a young age, and had recently passed away due to complications related to the disease.

Xiaohua was haunted by her inability to do more for her daughter's care, describing the anguish with which she and her husband looked at the itemized list of expenses and decided what was possible to pay and what wasn't. Without the reimbursements provided by basic insurance coverage for inpatient care, these costs were much more than she could afford on the piece-work salary she received as a janitorial employee at a Shanghai university:

We would only get a subsidy back home, anywhere else there isn't really anything. After my daughter got sick, I called my mother-in-law to talk to the party cadre there, and the cadre said he couldn't help. He said my mother in law had offended him. [...] After that, he didn't help at all. He did send us 7500 RMB (about 1100 USD), but that didn't even last a day. In one day, we spent over 18,000 RMB (about 2700 USD).

Members of the university community came together to support Xiaohua and her daughter, defraying some of these impossible-sounding costs. Nevertheless, she was unable to pay many of the fees necessary for her daughter's treatment. This inability to access state benefits reflects the function of the hukou system's division of government benefits between "temporary" and "official" residents: Because Xiaohua's daughter was registered as a resident of a village in Jiangsu province, that local government was legally responsible for the burden of her medical care. However, spatial inequalities in the quality and availability of public health service, which can roughly be understood along a rural-urban divide, have increased substantially in the wake of marketization (Zhang and Kanbur 2005). Despite healthcare reforms implemented between 2009 and 2012, which attempted to direct more resources toward healthcare provision in rural and 
lower-income areas, recent research indicates that these disparities remain. Furthermore, most migrants dependent on basic insurance, which is administered locally according to hukou status, and remains non-portable (Y. Li et al. 2016).

Similar questions revolving around the provision of health care for migrants are hotbutton political issues in the United States, and have led to policies that explicitly attempt to prevent noncitizens from accessing publicly funded health care services (Berk and Schur 2001). This debate, commonly framed in the West around questions of "deservingness", ties the legal question of who should have access to health care to issues of community belonging and membership (Willen 2012). The spatialized relationships between belonging, deservingness, and law that are invoked in Xiaohua's dilemma are strikingly similar to those present in debates over the provision of resources to international migrants: While local communities understood Xiaohua's daughter as deserving of care, the legal system made no accommodation for her as a "temporary" resident. By virtue of her legal status as attached to a home community that could not provide for her, Xiaohua's daughter was legally understood as undeserving of care, and functionally excluded from access to treatment.

Importantly, this citizenship distinction was made despite the mobilization of officially resident community members, who raised money to pay the medical bills that Xiaohua was unable to meet. In the U.S., a parallel dynamic famously played out in the context of MexicoU.S. migration for Jesica Santillan: While many commentators viewed her receipt of donated organs as emblematic of "wasteful" medical expenses on non-members of the (legal) US polity, local residents also contributed to a fund for her medical care (Chavez 2008, 129). In both cases, narratives of scarcity are tied to conceptions of belonging, and the benefits of citizenship are reserved for those with the privileges of having been born into the fold - or with the social and economic resources necessary to modify their status. 
It is important to recognize that while discourses of scarcity and deservingness are employed to justify exclusion of migrants, there are also real concerns about the availability of funds necessary to provide social welfare to migrants. Recent work demonstrates that in most migrant-receiving cities, including Shanghai, the potential cost of providing services to nonhukou migrant populations would exceed local governments' financial capacities (Zhang [1] and Li 2016). A study focused on Shanghai in particular shows that while the indirect economic benefits provided by migration are vast, migrants' direct contributions to local government coffers are insufficient to cover the necessary expenditures that would be incurred if the hukou system were liberalized. At the same time, because officially-employed migrant workers pay into social security systems but are unable to make those payments portable, the establishment of a system of continued circulation provides a widely unrecognized subsidy to urban social security that in fact exceeds revenue garnered through taxation (Zhang [1] 2015).

In this context, the incentives that lead Shanghai to manage the provision of hukou to migrants are driven by the city's territorial and financial limitations. However, this division ultimately rests on the ability to discursively construct migrants as noncitizen outsiders, whose (lack of) legal status separates them them from permanent urban citizens. The result is a system in which migrants are sorted according to their potential contributions to the city, with those deemed less deserving rendered unable to develop ties in the city, and pushed into circular migration. Ping Chenguang, a former member of the population statistics department who worked alongside Zhu Baiyue, explains how this population of outsiders becomes a population to be managed, with the goal of diminishing social expenditures:

When [mass migration] started, the migrants would be just one person coming in. But then they would marry, and if they would marry then they would have children, and then if the partner was originally from the same hometown, then that's another person coming in. And then they have a kid, that's another person. Then maybe their parents realize that it's really good here, and they come as well. So the problem of that one person's original 
social security, the government has to bring that up and consider it. And then the problem of that migrant's children's education. And then, with that person's parents coming, there are medical questions - they have to go to the doctor, this kind of thing. So this problem emerges and accumulates bit by bit.

The problem of migrants' potential need for social services is regulated through the system of temporary residence permits, in which migrants are allowed to enter Shanghai and work relatively freely, but are only offered the opportunity to formalize their status and receive cityfunded benefits in relatively few instances, when their assumed contributions to metropolitan government coffers render them desirable as new urban citizens.

There are, of course, significant differences between the kind of urban citizenship established in Shanghai and most national citizenships. In particular, territorial boundaries are not militarized, as they are in international contexts, and migrants do not need a visa or passport to enter Shanghai, although there are what amounts to border controls that check and register vehicles and license plates upon entry. Furthermore, most migrants - even those who are undocumented, having failed to register as temporary residents - are mostly not under the same threat of deportation faced by undocumented migrants in the United States or much of Europe, although Sarah Swider's recent work shows that many migrants in precarious working conditions do in fact face removal to their home villages (Swider 2015), and Li Zhang's description of the en-masse demolition and displacement of migrant communities in Beijing in the late 1990s shows form of intensive deportation and displacement aimed at migrants (Zhang [2] 2001). I read these differences as relatively minor: The legal structure does provide opportunities for entry-exit monitoring and deportation, and although they do not function in precisely the same ways as in the context of the Euro-American deportation regime (a term borrowed from De Genova and Peutz 2010), they could be made to do so.

Ultimately, the similarities in underlying motivations between Shanghai's implementation 
of the hukou system and international citizenship and migration policies outweigh their differences, troubling the assumption that citizenship exclusion operates solely at the national level. As I elaborate in the following section, the division between locals and outsiders created by the hukou system has resulted in the incentivization of circular migration and the development of sophisticated systems for determining what migrants are worthy of membership. As with the construction of insider-outsider divides around citizenship, both kinds of managerial responses can be compared to similar processes in international bordering.

\section{Section 3.2 Hukou as Migration Management Strategy}

This section will examine the hukou system through the lens of migration management, connecting it to scholarship on international bordering processes that treats the international border not as a firm boundary line, but as a managerial instrument through which governments are able to control certain aspects of the population. In particular, I discuss the ways that China's migration-management system functions to promote circular migration, and argue that the system of temporary residence permits and the establishment of a points system for hukou transfer function as instruments of flexible inclusion, paralleling similar policies established in the context of international borders.

Municipal government in Shanghai, like other large urban governments in China and many migrant-receiving countries worldwide, has responded to real and perceived threats of an "outsider" population through the implementation of management strategies that attempt to minimize costs of migration without diminishing the myriad benefits of migrant labor. These management strategies have evolved through reforms to the hukou system, culminating in the development of sophisticated legal and social systems that allow flexible movement and encourage circulation, but restrict belonging and possibilities for migrants to settle in urban areas. 
Ping Chenguang continues, describing the ways that migrant populations become divided into desirable and undesirable sectors as the hukou system transitions into a new, more effectively managerial model:

[In terms of] Shanghai and Beijing, as large cities, their capacity for admission of migrants is their main management problem. [...] The migrant population in Shanghai can get jobs very, very quickly. And this this way, the risks are really high. This sector is something that there's no real way to channel or really manage. We're using the temporary residence permit model to manage this to some extent, and according to several conditions they can very slowly be welcomed into the hukou system's management model, where they can then get healthcare, old-age insurance, and education for their children. But this is just one part - that is to say, the better half of the floating population. But the other half, this mediocre, unstable crowd, this part is relatively more troublesome, and if you don't manage it, you don't constrain it, the whole countryside will come. [...] Through the history of this process, you can see a development from previous simplistic management to a more developed management model.

While Ping points out the difficulty of effectively controlling a population of temporarilyregistered migrants, she nevertheless stresses that such a population must be managed, and that in order to do so it is important to separate out the valuable "better half" from the "crowd" of undistinguished migrants. As I argue below, these goals are accomplished in part through the establishment of points system that clarify divides between deserving and undeserving migrants, and hukou policies that incentivize circular migration, both by maintaining legal ties to home and by rendering migrants unable to become legal urban citizens in Shanghai.

Scholarly work has long recognized the similarities between patterns of circular migration within China and in the international context. The earliest scholarly comparison between Chinese internal movement and international migration came in 1997, when Kenneth Roberts published a now-classic article in which he aligned China's floating population with undocumented Mexican migrant workers in the United States (K. D. Roberts 1997, 249). Roberts notes that the disparity of fortunes that separate China's urban metropoles from the rest of the country is similar to the gap in incomes and wealth that exists between the United States 
and Mexico, and argues that the ways that Chinese migrants maintain their connections to hometowns while working in large cities mirror the patterns of circular, seasonal migration that characterized migration between Mexico and the United States at the time. ${ }^{3}$ More recently, Cindy Fan's definitive review of statistical and qualitative data on China's floating population and the hukou system follows up on Roberts' comparison, paying particular attention to the connections that migrants maintain to farmland in their home villages (Fan 2008, 7).

These attachments, which are legal as well as sentimental, have a powerful effect in drawing migrants back home: For migrants and their family members I interviewed at home in a rural village in Anhui province, the combination of legal and familial attachments, local identity, and borders erected against their membership clearly shaped their trajectories. Liu Ling Ling, who I interviewed in the small storefront in Taoyangcun that she opened using funds that her husband sent back from itinerant construction labor in Shanghai and Jiangsu provinces, gave an account that shared aspects with most other migrants I spoke to: Her husband, a carpenter, felt forced to go out to work in order to pay education costs for his children, since there were no good work opportunities in their village. As a construction worker, he moves around year-byyear, never staying in one place for long, and always coming home during rest periods when there was no work - as a result, her family had never considered moving for longer periods or seeking family unification anywhere outside the village.

Even for migrants whose trajectories draw them to one place for long periods feel the social and legal divisions that prevent them from settling into host communities. $\mathrm{Li} \mathrm{Li}$, a nanny I interviewed in Anhui as she waited for a bus that would take her back to Shanghai, had worked

3 While this comparison was particularly apt at the moment, more recent developments in U.S. border policy that make border crossing more difficult and dangerous have reduced possibilities for border crossing and to some extent disrupted patterns circular migration. (Nevins 2010) 
for the same family for several years, but clearly pointed out the intersection of social exclusion and incentivized legal ties to Taoyangcun inherent in her hukou status:

All around the world, in every country, any region, you will have this kind of [conflict] between the poor and the rich, regardless of where you are. It's just like when we Chinese leave the country, many people look down on us. Regardless of whether you are from Shanghai or wherever, it's the same. So, it's not just Shanghai, this problem is worldwide. [...] Right now, rural hukou is actually pretty good. You have land. Right now some of those who can transfer their hukou don't want to, because we rural people have fields to plant, we have land, so we're not willing to change. As a result, urban hukou is basically no good: If one was to change their hukou, they wouldn't have anything anymore. As a result, we would rather have agricultural hukou, so that our family can keep the land.

This difficult position can easily be related to the practical and sentimental calculations many international migrants make when deciding to pursue or forego naturalization in their host country, in which security for self and family plays an important role in the decision-making process (Leitner and Ehrkamp 2006). Importantly, however, legal ties to rural land are consolidated under the hukou system in such a way as to create a binary choice between land tenure and urban citizenship. As Li Li herself makes clear, the potential value of citizenship is not sufficient for her to leave behind her attachment to her home. Still, the value she sees in her rural hukou and attachment to Taoyangcun does not diminish the import of the borders she crosses when traveling to Shanghai:

Whenever sons and daughters go out to work, our home is still here. We will eventually get homesick and want to return. Out there, it is impossible to assimilate. We aren't strong enough, we don't have the ability. If I had that kind of ability, we wouldn't be talking about Shanghai - I would want to go out and see the whole world.

The boundaries that Li Li navigates when she goes out to work in Shanghai clearly divide Shanghai and rural Anhui. However, it is important not to overstate the significance of the hukou system in itself as it interacts with overlapping systems that classify populations and regulate life chances. While Li Li's status as an outsider in the hukou system helps make it impossible for her to assimilate, she does not place blame on the legal system that allows her and her family to 
retain the stability offered by control of land in Anhui. Rather, she points to class divides, which for her function alongside the specific legalities of the hukou system as salient tools for division. In this sense, the hukou system coincides with perceptions of class as well as local and regional attachments that are crucial elements shaping the identities of urban (non)citizens, for migrant workers in particular (Zhang [2] 2001, 31; Pun 2005, 121).

Even when circular migration patterns collapse and migrants reside in Shanghai in the long term, it is impossible for most to come to identify as locals. Lao Jin, an older male migrant I interviewed in Shanghai, had spent more time as a migrant worker than anyone else I interviewed, first arriving in Shanghai from Anhui province in September 1989, just after the opening of food markets made such a journey possible. After working for over a decade as a roadside grain peddler and moving back and forth between the city and his hometown, he stayed in Shanghai more and more permanently, working various jobs before arriving at his current position, delivering drinking water for a local subsidiary of the multinational giant Nestle. Despite living in Shanghai for over twenty years with constantly-renewed temporary residence certificates, his perspective on the policy echoes the rhetoric of management and stability that motivates the construction of borders through hukou:

"This governmental policy is set up to maintain a proportionate population - if it was loosened for even a day, everyone would want to come into Shanghai. It would be chaos."

For Lao Jin, the question of whether the hukou system is unfair was not worth considering: For him, individuals are naturally attached to their places of origin. To help me, a foreigner, understand how he could never belong in Shanghai, he directly pointed to national divides as a natural point of comparison:

Interviewer: Do you think that the hukou system's divisions between rural and urban are fair?

Lao Jin: I don't really have an opinion. I haven't thought about it that much. Just as someone born in China doesn't consider the question of becoming American, 
a person should have a place where they belong. [For example] when you you come here, you are still American. So I just think, I am an Anhui person."

Interviewer: So you think, actually, that your hukou helped gave you a feeling of belonging?

Lao Jin: $\quad$ It's just like, if you're an Anhui person and I'm an Anhui person, we feel closer, warmer (qinqie). I think it's very good.

Much like the national citizenship policies that Lao Jin draws on for comparison, the hukou system rests on and simultaneously supports an understanding of spatialized difference that includes but also stretches beyond the legal system itself.

These experiences of not-belonging in Shanghai demonstrate the power of a legal and cultural system that makes inclusion impossible for the majority of migrants who come to live and work there, be it in the short or long term. The mechanics of this process should sound familiar to many readers familiar migration and citizenship policy: Legal exclusion through border policy and social exclusion from host communities reinforce each other, as Gregory Feldman argues in his analysis of the European border regime under the Schengen agreement (2011). Europe has seen a confluence between neo-nationalist fears of drains on services from "foreigners" and neoliberal economic programs which appreciate the value of flexiblized labor forces. Essentially, racist social exclusion prevents migrants from feeling at home, while border control mechanisms reinforce this condition of unsettled temporariness in the realm of the law.

As an analogue to "temporary" or "guest" worker programs that create legal statuses for labor migrants who are nonetheless barred from citizenship, the establishment of flexible inclusion and points systems within the hukou system not only recalls the historical trajectory of U.S. and European migration (see Surak 2013), but also aligns with current trends in border and migration policy. Social exclusions based on language, ethnicity, and local identity work together with a flexible labor regime to create a situation in which migration management agencies champion a flexible regime of migration management that attempts to "regularize, 
encourage, and direct circular migration" in order to meet economic needs, while ensuring that migration is temporary, and migrants will eventually return to their countries of origin (Feldman 2011, 158-59). A similar trend has led Canada's Temporary Foreign Worker program to triple in size since the early 2000s, diminishing access to services intended to integrate migrants in favor of increased temporary labor migration (E. S. Roberts 2014).

While most of the migrants I spoke to were unable to consider the possibility of settling in as official Shanghai residents, migrants who are potentially included by the hukou system see a very different landscape, akin to the various "flexible" schemes in the North American context that in fact make borders more porous, albeit only to certain privileged classes of travelers who are able to exempt themselves from many of the inconveniences, difficulties, and outright blockages that emerge through the securitization of borders (Sparke 2006). Methods of securing urban hukou have existed throughout the duration of the system's implementation: Besides official job transfers and related forms of (centrally) "planned migration", cities have offered "blue stamp" programs that permitted migrants to purchase legal residence permits that - in much the same sense as programs of legal permanent residence in the United States - could be convertible to full local residence status following a definite period of good conduct (Chan and Zhang [1] 1999, 839). However, "blue stamp" hukou was deprecated in the early 2000s, and has since been replaced by new entry-condition based "points" systems (Wang 2004). These systems reveal yet more parallels between migration management through the hukou system and across international borders.

Shanghai has played a leading role among Chinese cities in the development of new hukou policy, and implemented China's first points system for hukou eligibility in 2004, which was designed specifically to filter talented migrants from the population of potential hukou applicatns. A similar policy - purportedly more open to hukou transfers by migrant workers - 
was adopted by cities in Guangdong province in 2011, while Beijing rolled out its own system in the summer of 2016 (Zhang [1] 2012, 510; Leng 2016). Under the Shanghai points system, would-be transferees are scored on various categories, including business and academic credentials and the qualifications of the candidate's employer. If a candidate meets the requirements, they then become eligible to apply immediately for Shanghai hukou. Still, these methods of transfer are subject to strict quotas, put in place to ensure that the population of "new Shanghai People" (xin Shanghai ren) does not grow out of hand (Zhang [1] 2012).

These systems are functionally analogous to those implemented at the nation-state level. "Blue Stamp" hukou transfers formerly conferred a probationary status that provided most of the benefits of full hukou transfer, and facilitated the eventual conversion into full membership. The resulting status permitted long-term legal residence and granted significant rights to migrants while withholding the status of full membership in the community. The function of this program was similar to visa programs that permit the "purchase" of long-term visa status through investment visas, a common practice worldwide, with US E-2 and EB-5 investment visas being a preferred method for wealthy migrants to obtain status in the United States, as well as "business class" migration categories in Canada which have been historically favored by wealthy Chinese migrants to North America (Galabuzi 2006; Young 2015). Under current regulations, the points system implemented in Shanghai offers a similar function, and operates in direct parallel to similar systems for the recruitment of skilled migrants in the international context, where nations such as Canada, Denmark, New Zealand, and Australia use systems of points to categorize the human capital migrants bring with them when they enter the country (Papademetriou and Sumption 2011).

In China as well as internationally, the boundaries that demarcate spatial belonging are applied unevenly, and function not to prevent movement altogether, but to filter and direct it, 
facilitating incorporation for migrants whose positions are seen as desirable and excluding others who are understood as not belonging (Andrijasevic and Walters 2010). Points systems, as policies that establish strong boundaries for some and freer movement for others constitute part of a broader, global regime of flexible inclusion under which "the boundaries between the dynamics of filtering, subordination, and labor market discrimination that once occurred at the international border and those that take place within the bounded spaces of national societies have been blurred" (Mezzadra and Neilson 2013, 159). At the same time, migrant-receiving societies cannot afford to fully exclude migrants: someone must build the skyscrapers, man the factory lines, and staff the kitchens. This is accomplished through the maintenance of circular migration - a system that, as Sarah Swider argues in the case of migrant construction workers, creates a class of "permanently temporary" laborers (Swider 2015, 54) whose productive labor can be geographically separated from the spaces where it is reproduced. In these ways, then, the hukou system and the "floating population" that it constructs are particularly demonstrative of the ways in which differential inclusion of migrants - whether intra-national or international helps manage and control a reliable workforce.

\section{Conclusion}

As I have argued throughout this article, international bordering processes and China's internal migration controls share important functions, including the management of migrant labor and the safeguarding of state resources for the benefit of officially resident populations. As a result, they are structured in remarkably similar ways. While past scholarship has recognized that the hukou system functions as a de-facto system of urban citizenship, researchers have not yet connected recent developments in the hukou system to theoretical developments in our understandings of international bordering processes. Drawing this theoretical connection is particularly important in light of recent attempts to unsettle the spatialities of international 
bordering and citizenship, which nonetheless continue to take national borders and the territories they enclose as their object of study.

The spatialized controls on legal belonging in China described here trouble this implicit link between citizenship, bordering, and national territory: In China, cities themselves set immigration policies, provide benefits, and calculate the costs and benefits of migration management policies that legally distinguish those who belong from those who do not. The policies that they enact, as well as the effects these policies have on migrants themselves, demonstrate striking parallels with the policy landscape that many international migrants traverse.

The consistency of these parallels has implications for theories of Chinese migration and international migration alike. The large-scale implementation of temporary residence permits under the hukou system provides a mirror for legal reform policies in Western migrant-receiving countries that have considered regularization of status for undocumented migrants without providing a path to full membership. The alienation faced by millions of Chinese "temporary residents" should give pause to proponents of the kinds of large-scale guest worker programs such as Canada's recent expansion of the Temporary Foreign Worker program, which now admits more migrants than permanent immigrants nationwide (No One Is Illegal 2015). The exclusion of China's floating population from urban membership should also serve as a warning to proponents of new urban-level citizenship policies, demonstrating that a simple re-scaling of existing citizenship norms replicates much of the exclusionary nature of national citizenship, and that a new ethics of belonging is necessary (c.f. Bauder 2013).

Through juxtapositions of the hukou system and national citizenship and border policies, it is clear that bordering and the management of human mobility cannot be understood as coming under the exclusive purview of the nation-state. Nonetheless, this analysis is necessarily limited. Further research should provide deeper, more specific understandings of the circuits of legal 
production that inform both the hukou system and national border policies. By delving into the

legal, economic, and cultural geographies of the hukou system and other bordering processes

taking place apart from or alongside nation-state boundaries, it should be possible to develop

critical understandings borders and bordering that draw connections between systems based on

shared functionalities. It is only bearing these connections in mind that critical scholarship will

be able to develop a politics confronting the multi-sited and multi-scalar nature of bordering

systems.

1. Amilhat-Szary, Anne Laure, and Frédéric Giraut. 2015. “Borderities, the Politics of Contemporary Mobile Borders (Conference Presentation)." In Enforcing Borders, Controlling Immigration 2: Governmental Assemblages. Annual Meeting of the American Association of Geographers, Chicago, IL.

2. Andrijasevic, Rutvica, and William Walters. 2010. “The International Organization for Migration and the International Government of Borders." Environment and PlanningPart D 28 (6): 977.

3. Bauder, Harald. 2013. “Domicile Citizenship, Human Mobility and Territoriality." Progress in Human Geography, August, 309132513502281. doi:10.1177/0309132513502281.

4. Berk, Marc L., and Claudia L. Schur. 2001. “The Effect of Fear on Access to Care Among Undocumented Latino Immigrants." Journal of Immigrant Health 3 (3): 151-56. doi:10.1023/A:1011389105821.

5. Bloemraad, Irene, Anna Korteweg, and Gökçe Yurdakul. 2008. “Citizenship and Immigration: Multiculturalism, Assimilation, and Challenges to the Nation-State." Annual Review of Sociology 34 (1): 153-79. doi:10.1146/annurev.soc.34.040507.134608.

6. Bocarejo, Diana. 2012. “Emancipation or Enclosement? The Spatialization of Difference and Urban Ethnic Contestation in Colombia." Antipode 44 (3): 663-83. doi:10.1111/j.1467-8330.2011.00889.x.

7. Bosniak, Linda. 2008. The Citizen and the Alien: Dilemmas of Contemporary Membership. Princeton University Press.

8. Buckley, Cynthia. 1995. “The Myth of Managed Migration: Migration Control and Market in the Soviet Period." Slavic Review 54 (4): 896-916. doi:10.2307/2501398.

9. Chan, Kam Wing, and Will Buckingham. 2008. "Is China Abolishing the Hukou System?" The China Quarterly 195 (September): 582-606. doi:10.1017/S0305741008000787.

10. Chan, Kam Wing, and Li Zhang [1]. 1999. “The Hukou System and Rural-Urban Migration in China: Processes and Changes." The China Quarterly 160 (December): 818-855. doi:10.1017/S0305741000001351.

11. Chavez, Leo. 2008. The Latino Threat: Constructing Immigrants, Citizens, and the Nation, Second Edition. Stanford University Press.

12. Cheng, Tiejun, and Mark Selden. 1994. "The Origins and Social Consequences of China's Hukou System." The China Quarterly, no. 139 (September): 644-68.

13. China Statistical Bureau. 2014. "2013 Report of the National Peasant Worker Monitoring Survey (Quanguo Nongmingong Jiance Diaocha Baogao)." 
http://www.stats.gov.cn/tjsj/zxfb/201405/t20140512_551585.html.

14. Coleman, Mathew, and Austin Kocher. 2011. "Detention, Deportation, Devolution and Immigrant Incapacitation in the US, Post 9/11." The Geographical Journal 177 (3): 228-37. doi:10.1111/j.1475-4959.2011.00424.x.

15. Davis, Mike. 2006. Planet of Slums. New York: Verso.

16. De Genova, Nicholas, and Nathalie Peutz. 2010. The Deportation Regime: Sovereignty, Space, and the Freedom of Movement. Duke University Press.

17. Fan, C. Cindy. 2008. China on the Move: Migration, the State, and the Household. Routledge.

18. Feldman, Gregory. 2011. The Migration Apparatus: Security, Labor, and Policymaking in the European Union. Stanford University Press.

19. Freeman, James P. 2003. "City of Walls: Crime, Segregation, and Citizenship in São Paulo. Teresa P. R. Caldeira." Urban Geography 24 (2): 183-84. doi:10.2747/02723638.24.2.183.

20. Fu, Daniel, Chang Ying Li, He Xue Song, and Keung Wong. 2007. “Rural Migrant Workers in Urban China: Living a Marginalised Life." International Journal of Social Welfare 16 (1): 32-40. doi:10.1111/j.1468-2397.2007.00475.x.

21. Galabuzi, Grace-Edward. 2006. Canada's Economic Apartheid: The Social Exclusion of Racialized Groups in the New Century. Canadian Scholars' Press.

22. Gilbert, Liette. 2009. "Immigration as Local Politics: Re-Bordering Immigration and Multiculturalism through Deterrence and Incapacitation." International Journal of Urban and Regional Research 33 (1): 26-42. doi:10.1111/j.1468-2427.2009.00838.x.

23. Goodburn, Charlotte. 2009. "Learning from Migrant Education: A Case Study of the Schooling of Rural Migrant Children in Beijing." International Journal of Educational Development, Education and Development in Contemporary China, 29 (5): 495-504. doi:10.1016/j.ijedudev.2009.04.005.

24. - - - 2014. "The End of the Hukou System? Not Yet." Policy Paper 2. China Policy Institute Policy Papers. Nottingham: China Policy Institute. https://www.nottingham.ac.uk/cpi/documents/policy-papers/cpi-policy-paper2014-no-2-goodburn.pdf.

25. Gullette, Gregory S. 2014. "Rural-Urban Hierarchies, Status Boundaries, and Labour Mobilities in Thailand." Journal of Ethnic E Migration Studies 40 (8): 1254-74. doi:10.1080/1369183X.2013.836959.

26. Guo, Zhonghua. 2014. "Nationality, Hukou, and Ethnicity: The Institutional Structure of Citizenship in Contemporary Mainland China." Cambridge Journal of China Studies 9 (4): 1-19.

27. Houtum, Henk van. 2010. “Human Blacklisting: The Global Apartheid of the EU's External Border Regime." Environment and Planning D: Society and Space 28 (6): 957 976. doi:10.1068/ d1909.

28. Hui, Eddie Chi Man, Ka Hung Yu, and Yinchuan Ye. 2014. “Housing Preferences of Temporary Migrants in Urban China in the Wake of Gradual Hukou Reform: A Case Study of Shenzhen." International Journal of Urban and Regional Research 38 (4): 1384-98. doi:10.1111/j.1468-2427.2012.01176.x.

29. Isin, Engin Fahri. 2002. Being Political: Genealogies of Citizenship. U of Minnesota Press.

30. - - - 2004. "Citizens Without Nations." Environment and Planning D: Society and Space 30 (4): 450-67.

31. Jirón, Paola. 2010. "Mobile Borders in Urban Daily Mobility Practices in Santiago de Chile." International Political Sociology 4 (1): 66-79. doi:10.1111/j.17495687.2009.00092.x. 
32. Lai, Fang, Chengfang Liu, Renfu Luo, Linxiu Zhang, Xiaochen Ma, Yujie Bai, Brian Sharbono, and Scott Rozelle. 2014. "The Education of China's Migrant Children: The Missing Link in China's Education System." International Journal of Educational Development 37 (July): 68-77. doi:10.1016/j.ijedudev.2013.11.006.

33. Leitner, Helga, and Patricia Ehrkamp. 2006. “Transnationalism and Migrants' Imaginings of Citizenship." Environment and Planning A 38 (9): 1615 - 1632. doi:10.1068/a37409.

34. Leng, Shumei. 2016. "Beijing Introduces New Points System for Getting Capital Hukou." Global Times, August 16. http://www.globaltimes.cn/content/1000692.shtml.

35. Li, Wei. 2013. "'Hukou' Status, Place Affiliation and Identity Formation: The Case of Migrant Workers in Metropolitan Beijing." Procedia Environmental Sciences, The 3rd International Conference on Sustainable Future for Human Security, SUSTAIN 2012, 3-5 November 2012, Clock Tower Centennial Hall, Kyoto University, JAPAN, 17: 842-51. doi:10.1016/j.proenv.2013.02.102.

36. Li, Y., Y. Sun, Y. Zhang, D. Yi, C. Ma, and S. Ma. 2016. "Rural-urban Disparity in Health Care: Observations from Suzhou, China." Public Health In Press. doi:10.1016/j.puhe.2016.03.026.

37. Li, Zhigang, and Fulong Wu. 2008. "Tenure-Based Residential Segregation in PostReform Chinese Cities: A Case Study of Shanghai." Transactions of the Institute of British Geographers 33 (3): 404-19. doi:10.1111/j.1475-5661.2008.00304.x.

38. McNevin, Anne. 2013. Contesting Citizenship: Irregular Migrants and New Frontiers of the Political. Columbia University Press.

39. Mezzadra, Sandro, and Brett Neilson. 2013. Border as Method, Or, the Multiplication of Labor. Duke University Press.

40. Nevins, Joseph. 2010. Operation Gatekeeper and Beyond: The War On "Illegals" and the Remaking of the U.S. - Mexico Boundary. Routledge.

41. Newman, David, and Anssi Paasi. 1998. "Fences and Neighbours in the Postmodern World: Boundary Narratives in Political Geography." Progress in Human Geography 22 (2): 186-207. doi:10.1191/030913298666039113.

42. No One Is Illegal. 2015. "Legislating Discrimination in Canadian Immigration." Vancouver, Unceded Coast Salish Territories. neverhome.ca.

43. Papademetriou, Demetrios, and Madeline Sumption. 2011. "Rethinking Points Systems and Employer-Selected Immigration." Washington, D.C.: Migration Policy Institute.

44. Parker, Noel, and Nick Vaughan-Williams. 2009. "Lines in the Sand? Towards an Agenda for Critical Border Studies." Geopolitics 14 (3): 582-87. doi:10.1080/14650040903081297.

45. Pipko, Simona, and Albert J. Pucciarelli. 1985. “Soviet Internal Passport System, The." International Lawyer (ABA) 19: 915.

46. Prescott, J. R. V. 1987. Political Frontiers and Boundaries. London ; Boston: Allen \& Unwin.

47. Pun, Ngai. 2005. Made in China: Women Factory Workers in a Global Workplace. Duke University Press.

48. Roberts, Elizabeth Sarah. 2014. “The Classifying Work of Immigration Policies in Canada: A Critical Analysis of the Temporary Foreign Workers Program and Access to Settlement Services." Thesis, University of Toronto. https:/ /tspace.library.utoronto.ca/handle/1807/68028.

49. Roberts, Kenneth D. 1997. “China's 'Tidal Wave' of Migrant Labor: What Can We Learn from Mexican Undocumented Migration to the United States?" International Migration Review 31 (2): 249-93. doi:10.2307/2547220. 
50. Rumford, Chris. 2008. "Introduction: Citizens and Borderwork in Europe." Space and Polity 12 (1): 1-12. doi:10.1080/13562570801969333.

51. Scott, James Wesley, and Henk van Houtum. 2009. "Reflections on EU Territoriality and the 'bordering' of Europe." Political Geography 28 (5): 271-73. doi:10.1016/j.polgeo.2009.04.002.

52. Shanghai Statistical Bureau. 2011. "Shanghai Statistical Yearbook." China Statistics Press. http:/ / www.stats-sh.gov.cn/tjnj/sh2011e.htm.

53. Smart, Alan, and Josephine Smart. 2001. "Local Citizenship: Welfare Reform Urban/Rural Status, and Exclusion in China." Environment and Planning A 33 (10): 1853 - 1869. doi:10.1068/a3454.

54. Solinger, Dorothy J. 1999a. “Citizenship Issues in China's Internal Migration: Comparisons with Germany and Japan." Political Science Quarterly 114 (3): 455-78. doi:10.2307/2658206.

55. - - - 1999b. Contesting Citizenship in Urban China: Peasant Migrants, the State, and the Logic of the Market. University of California Press.

56. Sparke, Matthew B. 2006. “A Neoliberal Nexus: Economy, Security and the Biopolitics of Citizenship on the Border." Political Geography 25 (2): 151-80. doi:10.1016/j.polgeo.2005.10.002.

57. Sun, Wanning. 2014. Subaltern China: Rural Migrants, Media, and Cultural Practices. Rowman \& Littlefield.

58. Surak, Kristin. 2013. “Guestworker Regimes: A Taxonomy.” The New Left Review, no. 84: 84-102.

59. Swider, Sarah. 2015. Building China: Informal Work and the New Precariat. Ithaca, NY: Cornell University Press.

60. Vaughan-Williams, Nick. 2008. “Borderwork beyond Inside/Outside? Frontex, the Citizen-Detective and the War on Terror." Space and Polity 12 (1): 63-79. doi:10.1080/13562570801969457.

61. Walker, Kyle E., and Helga Leitner. 2011. “The Variegated Landscape of Local Immigration Policies in the United States." Urban Geography 32 (2): 156-78. doi:10.2747/0272-3638.32.2.156.

62. Wang, Fei-Ling. 2004. "Reformed Migration Control and New Targeted People: China's Hukou System in the 2000s." The China Quarterly, no. 177 (March): 115-32.

63. Willen, Sarah S. 2012. “Migration, 'illegality,' and Health: Mapping Embodied Vulnerability and Debating Health-Related Deservingness." Social Science $\mathcal{E}$ Medicine, Part Special Issue: Migration, "illegality", and health: Mapping embodied vulnerability and debating health-related deservingness, 74 (6): 805-11. doi:10.1016/j.socscimed.2011.10.041.

64. Wimmer, Andreas, and Nina Glick Schiller. 2002a. "Methodological Nationalism and the Study of Migration." European Journal of Sociology / Archives Européennes de Sociologie 43 (2): 217-240. doi:10.1017/S000397560200108X.

65. - - - 2002b. "Methodological Nationalism and beyond: Nation-state Building, Migration and the Social Sciences." Global Networks 2 (4): 301-34. doi:10.1111/14710374.00043 .

66. Young, Ian. 2015. “Chinese Millionaires Appear to Be Deserting Quebec's Immigrant Investor Scheme." South China Morning Post, April 9. http://www.scmp.com/comment/blogs/article/1761350/exclusive-chinesemillionaires-appear-be-deserting-quebecs-immigrant.

67. Zhang [1], Li. 2002. "Spatiality and Urban Citizenship in Late Socialist China." Public 
Culture 14 (2): 311-34.

68. - - - 2011. “The Political Economy of Informal Settlements in Post-Socialist China: The Case of Chengzhongcun(s)." Geoforum 42 (4): 473-83. doi:10.1016/j.geoforum.2011.03.003.

69. - - - 2012. "Economic Migration and Urban Citizenship in China: The Role of Points Systems." Population and Development Review 38 (3): 503-33. doi:10.1111/j.17284457.2012.00514.x.

70. - - 2015. “流动人口对城市的经济贡献剖析：以上海为例 (Estimating the Value of Migration: Floating Population's Contribution to Urban Revenue)." Renkou Yanjiu (Population Research) 39 (4): 57-65.

71. Zhang [1], Li, and Meng Li. 2016. “Local Fiscal Capability and Liberalization of Urban Hukou." Journal of Contemporary China 0 (0): 1-15. doi:10.1080/10670564.2016.1186362.

72. Zhang [1], Li, and Li Tao. 2012. "Barriers to the Acquisition of Urban Hukou in Chinese Cities." Environment and Planning A 44 (12): 2883 - 2900. doi:10.1068/a4551.

73. Zhang [2], Li. 2001. Strangers in the City: Reconfigurations of Space, Power, and Social Networks Within China's Floating Population. Stanford University Press.

74. Zhang, Xiaobo, and Ravi Kanbur. 2005. "Spatial Inequality in Education and Health Care in China." China Economic Review 16 (2): 189-204. doi:10.1016/j.chieco.2005.02.002.

75. Zhu, Lijiang. 2003. "Hukou System of the People's Republic of China: A Critical Appraisal under International Standards of Internal Movement and Residence, The." Chinese Journal of International Law 2: 519. 